\title{
CLARICE LISPECTOR'S RADICALITY TRANSLATED INTO THE ENGLISH-SPEAKING LITERARY SYSTEM ${ }^{1}$
}

\author{
Luana Ferreira de Freitas 22 \\ ²Universidade Federal do Ceará, Fortaleza, Ceará, Brasil
}

\begin{abstract}
This article aims to investigate whether Clarice's radical use of language was somehow achieved in translations and especially in the retranslations of her work into English, or whether this radicality itself made the Claricean legacy an obstacle to its absorption in the English-speaking literary system. I will deal with Perto do coração selvagem in Pontiero's (1990) and Entrekin's (2012) translations and the short story "A menor mulher do mundo" in Pontiero's (1960) and Dodson's (2015) translations. Keywords: Clarice Lispector; English-speaking literary system; Translation.
\end{abstract}

\section{A RADICALIDADE DE CLARICE LISPECTOR TRADUZIDA PARA O SISTEMA LITERÁRIO ANGLÓFONO}

\begin{abstract}
Resumo: O artigo tem como objetivo investigar se o uso radical de língua de Clarice foi, em alguma medida, alcançado nas traduções e especificamente nas retraduções de sua obra para o inglês ou se essa radicalidade em si fez do legado de Clarice um obstáculo à sua absorção no sistema literário anglófono. Lido com as traduções de Pontiero (1990) e Entrekin (2012) do romance Perto do coração selvagem e das traduções de Pontiero (1960) e Dodson (2015) do conto "A menor mulher do mundo".
\end{abstract} Palavras-chave: Clarice Lispector; Sistema literário anglófono; Tradução

\footnotetext{
${ }^{1}$ Paper presented at After Clarice: Lispector's Legacy International Conference, at the University of Oxford, on November 18, 2017.

${ }^{2}$ CAPES research grant holder (visiting researcher at Vrije Universiteit Brussel).
} 
"Sim que estava compreendendo as palavras, tudo o que elas continham. Mas apesar de tudo a sensação de que elas possuíam uma porta falsa, disfarçada, por onde se ia encontrar seu verdadeiro sentido" ${ }^{3}$

\section{Clarice $^{4}$ in English}

Clarice has been translated into English ${ }^{5}$ since 1960 by the likes of Gregory Rabassa, Elizabeth Bishop, Giovanni Pontiero, and Elizabeth Lowe. Clarice's fictional narrative is well represented in English with all her novels ${ }^{6}$ translated now. As to her short stories, besides the translations of Laços de família, A legião estrangeira e $A$ via crucis do corpo, Katrina Dodson's 2015 translation of Clarice's stories, The Complete Stories, and its success ${ }^{7}$ seem to point to the relative stability of Clarice's place in the Englishspeaking literary system.

The analysis here proposed stems from Benjamin Moser's project, that is, his Clarice's biography, Why This World: $A$ Biography of Clarice Lispector, the first compilation of all of Clarice's short stories, Complete Stories, above mentioned, and the retranslation of six of the most celebrated novels by Clarice: Perto do coração selvagem, A hora da estrela, A paixão Segundo G.H., Água viva, $O$ lustre, Um sopro de vida. The aim is to analyse how

\footnotetext{
${ }^{3}$ Perto do coração selvagem, part 1 , chapter "O banho", (29).

${ }^{4}$ In Brazil we refer to Clarice Lispector as merely Clarice instead of the more formal Lispector. The same phenomenon is observed with Machado de Assis, here merely Machado.

${ }^{5}$ For further discussion, see “A internacionalização de Clarice Lispector: A história clariceana em inglês", in http://dx.doi.org/10.5007/2175-7968.2017v37n2p40 ${ }^{6} \mathrm{O}$ lustre, The Chandelier, in English, has just been published by New Directions, translated by Magdalena Edwards and Benjamin Moser.

7 New York Times Editors' Choice, 100 Notable Books of 2015, 12 Best Book Covers of 2015; Best of 2015: New York Times, NPR, BBC, Vogue, Vanity Fair, BuzzFeed, Literary Hub, Flavorwire, Kirkus Reviews, Boston Globe, The Independent, National Post, San Francisco Chronicle, Al Día, Entropy, 3:AM Magazine, Hugo House, KQED; Top 5 Literary Stories of the Year, Literary Hub; Winner of the 2016 PEN Translation Prize among others.
} 
and if these retranslations considered Clarice's style, above all the rhythm of the narrative, unusual collocations, lexical choices and the combination of form and content in the author's writings.

The discussion of the translations into English of the novel Perto do coração selvagem, and the story "A menor mulher do mundo" by Clarice Lispector, here presented, will deal with the aesthetic treatment that the writer gave to these two texts and how her translators reacted to this radicality of her writing. The texts in exam were chosen mainly because of their translators: Giovanni Pontiero who translated Perto do coração selvagem, Laços de Família, A hora da estrela, Legião estrangeira, A descoberta do mundo and Cidade Sitiada; Alison Entrekin who besides translating Clarice's Perto do coração selvagem, translated among others Cidade de Deus by Paulo Lins, and Budapeste by Chico Buarque; and Katrina Dodson winner of the 2016 PEN Translation Prize with Complete Stories.

The analysis proposed will be carried out with two quotations by Levý in The Art of Translation in mind:

\begin{abstract}
The language of the source and the language of the translation are not directly commensurable. The verbal means of the two languages are not 'equivalent', so they cannot be converted mechanically. Meanings and their aesthetic values do not coincide precisely; consequently, the more significant the role of language in the artistic structure of the text, the more difficult translation becomes. $(2011,48)$

(..)

By contrast with original authors, whose individual language continually undergoes innovation, thereby contributing to the evolution of the domestic language, translators frequently remain prisoners of the stylistic patterns $(2011,54)$
\end{abstract}

Levý argues that the author of the source text is continuously in violation of his own language, which, according to him, is an inescapable characteristic of great works and that the translator, 
in turn, does not seek to innovate the source language along the lines of the source text, but conforms to established norms of the aesthetics of the target culture, which contributes to the short life of translations. The translation, because it tries to adapt to the local taste when launching a text from another culture, does not dare to challenge the target language. Radicality, then, is at best resumed, in part, in a movement that, in addition to subjecting the author's creativity to aesthetic values of another culture ${ }^{8}$, infantilises the target audience by denying them access to another aesthetic universe.

Before turning to the texts themselves, it is convenient to talk a little about this radicality in Clarice here presented. The radicality in question is translated into the author's use of language. The language in Clarice is no mere instrument for a plot: it is a protagonist in her writings. In Clarice, as in great writers, the complementarity between form and content is entangled, which hinders the work of the translator who tends, generally, to deal with prose and semantic translation.

In Clarice, the sublime is achieved through the trivial; it is in the routine triviality that the characters experience a certain Spinozan glimpse of the inevitability of their trajectories ${ }^{9}$. There is no salvation in this momentary understanding: the characters return to their daily lives resigned. As the action in these cases is internalised, this is reflected in the precariousness of the language in the quest to recreate the uneasiness generated by the revelation of the character.

${ }^{8}$ The case of Machado de Assis is exemplary in this sense. Machado, to justify his presence abroad, is often compared to Sterne, Shakespeare, Cervantes, Flaubert, among others. What is observed is the denial of intertextuality as a universal literary phenomenon. Sterne, for example, was an avid reader of Shakespeare and Cervantes and borrowed from both procedures and characters.

9 "There is no need to spend time in going on to show that Nature has no fixed goal and that all final causes are but figments of the human imagination". (2002, 239) Spinoza. Complete Works. Indianapolis: Hackett, 2002. 


\section{Perto do coração selvagem}

Perto do coração selvagem, whose first edition dates from the end of 1943, by the publisher A Noite, is Clarice's debut novel. Near to the Wild Heart is released in 1990 by New Directions with Pontiero's translation and postface ${ }^{10} .22$ years later, in 2012, Alison Entrekin's translation is released, Near to the Wild Heart, by the same publisher. The latter presents an introduction by Benjamin Moser.

Pontiero's and Entrekin's texts are, in general, clear and readable, but with quite different translation strategies: Pontiero tends more to his public, trying to transform Clarice into more a palatable product, whereas Entrekin tends to be closer to the Claricean text, maintaining original conciseness and defamiliarization. Pontiero's text is wordy as if he tried to untangle Clarice's text, clarify it.

A sentence in the chapter "O abrigo no professor" is exemplary of the different strategies of the translators: "Subitamente precisaria encontrá-lo, senti-lo firme e frio antes de ir embora." $(1994,110)$ Pontiero's version is "She had suddenly felt the need to meet him, to listen to him, unyielding and cold, before going away" (1990, 104), Entrekin opted for:" She had suddenly needed to see him firm and cold before leaving." (2012, 103) Pontiero used 7 additional words if compared to Entrekin's translation as he chooses to add "to listen to him" and uses "felt the need" instead of "needed".

Both translations follow the structure of the narrative proposed by the source text, that is, two parts, with nine and ten chapters respectively. In general, both translators are attentive to the rhythm of the narrative. There are, however, occurrences, more frequent in Pontiero, of change in punctuation or an attempt to reorganise the text, which necessarily changes configuration, rhythm, and effect of some fragments.

In the chapter "O banho", for example, there is a five-page paragraph corresponding to Joana's flow of consciousness.

${ }^{10}$ I used my previous analysis of Pontiero's translation as a starting point in "Perto do coração selvagem em inglês” in Cerrados, 2007, (279-285).

Cad. Trad., Florianópolis, v. 38, $n^{0}$ 3, p. 244-258, set-dez, 2018 
Pontiero divides the paragraph in two, breaking the feverish effect of the scene, without apparently any justification. The translator maintains the extension of the periods, but not all the dashes and ellipsis, thus reducing the silences of the narrative. Entrekin, in the same paragraph, breaks only the first sentence but retains both the length of the paragraph as dashes and ellipses.

The repetitions are essential for the organisation of the narrative contributing to its cohesion. The lexical choice is thoughtful, careful and never gratuitous. In the fragments quoted below, the words desejo and sede, used as synonyms, are mentioned three times respectively, having an evident effect in the text when creating a network of meaning. I quote the passages:

C: "Meu Deus, pelo menos comunicai-me com elas, fazei realidade meu desejo de beijá-las." $(1994,66)$

P: "Dear God, at least bring me into contact with them, satisfy my longing to kiss them." $(1990,61)$

E: "Dear God, at least allow me to communicate with them, satisfy my desire to kiss them." $(2012,58)$

C: "Não sinto loucura no desejo de morder estrelas, mas ainda existe a terra." $(1994,67)$

P: "I feel no madness in my desire to bite into stars, but the earth still exists." (1990, 62)

E: "I don't feel madness in my wish to bite stars, but the earth still exists." $(2012,59)$

C "E talvez meu desejo de outra fonte, essa ânsia que me dá ao rosto um ar de quem caça para se alimentar, talvez essa ânsia seja uma ideia - e nada mais." $(1994,69)$

P: "And perhaps my craving for another source, which gives me the expression of someone in search of food, perhaps this craving is a whim-and nothing more." $(1990,64)$

E: "And maybe my desire for another spring, this keenness 
that gives my face the look of one who hunts to eat, maybe this keenness is just an idea - and nothing more." $(2012,61)$

"Por que surgem em mim essas sedes estranhas?" $(1994,66)$

P: Why do these strange longings possess me? $(1990,61)$

E: Why do these strange thirsts grip me? $(2012,58)$

C: "Sempre, sem parar, distraindo minha sede cansada de pousar num fim." $(1994,67)$

P: "Always without stopping, distracting my weary desire to reach some final resting-place." $(1990,62)$

E: "Always, unstopping, diverting my weary longing to reach an end." $(2012,59)$

C: “(...) esses instantes não provam que sou capaz de satisfazer minha busca e que esta é sede de todo o meu ser e não apenas uma ideia?" $(1994,70)$

P: “(...) surely those moments prove that I am capable of fulfilling my quest and that this longing which consumes my whole being is not merely some whim?" $(1990,65)$

E: “(...) don't these instants prove that I am capable of fulfilling my quest and that this is the longing of my entire being and not just an idea?" $(2012,62)$

Pontiero used three distinct words for "desejo": longing, desire, and craving. Entrekin used desire twice and wish. For "sede", Pontiero uses longing twice and desire and, Entrekin uses longing twice and thirst. Despite Entrekin's satisfying thirst, the cohesion proposed by the narrative is broken. Pontiero inadvertently translating both "desejo" and "sede" for longing and desire interchangeably does not seem to have realised Clarice's writing method and does not perceive the connection between occurrences.

One of the aspects that draws attention in the Claricean text is the abundance of unusual collocations, resulting in defamiliarization, 
drawing the reader's attention to the linguistic material itself. Here are some examples with the respective translations:

C: “(...) um milagre partido em estrelas grossas, sérias e brilhantes." (1994, 66)

P: “(...) a miracle splintered into dense, solemn, glittering stars" $(1990,61)$

E: “(...) a miracle split into chunky, serious, twinkling stars” $(2012,58)$

C: “(...) chorar em notas largas, desesperadas e românticas” $(1994,66)$

P: "(...) weeping at length in tones of romantic despair." $(1990,61)$

E: "(...) crying in broad, desperate, romantic notes." $(2012,58)$

C: "Respirava opressa o perfume roxo e frio das imagens." $(1994,70)$

P: "I inhaled the overpowering odour, purple and cold, that emanated from the holy statues." $(1990,65)$

E: "I was breathing oppressed the cold, purple perfume of the statues." (2012, 62-3)

C: "Vagarosamente entristeceu de uma tristeza insuficiente e por isso duplamente triste." $(1994,75)$

P: "She slowly grew sad from a lack of sadness and was therefore twice as sad." (1990, 70)

E: "She slowly saddened with a sadness that was insufficient and thus doubly sad." $(2012,69)$

In these cases, the collocations are not linguistic phenomena specific to Brazilian Portuguese. In the examples above, we see the different positions of the translators as to the translation practice 
again. In the first three examples, Pontiero consistently seeks to normalise the text by organising, rearranging, and changing grammatical class for anglophone eyes and ears. Entrekin, on the other hand, consciously maintains the defamiliarization caused to Brazilian eyes and ears.

In such cases, there is no real obstacle to translation, or in other words, Clarice's original collocations pose no challenges at a linguistic level, nor is this resource, however daring, invented by the author. So why does Pontiero try to normalise Clarice in English? I believe that this tendency can be explained by Levy's already mentioned contrast between the freedom one takes with the language itself in the source text, a very welcome disregard when dealing with creativity and imagination, and a certain tendency towards acceptability regarding the target audience.

Regarding the last example, Pontiero changed the meaning proposed in the narrative: it was not that she lacked sadness, but that it was not enough. Entrekin, on the other hand, kept not only the sense but also the parallelism established by entristeceu, tristeza and triste with saddened, sadness and sad.

Regarding both translations of the novel, it is noticeable that Pontiero prioritises content and his readership by naturalising Clarice's singular style. Entrekin, on the other hand, endeavours to convey not only the plot but the author's unique use of language with its instances of defamiliarization, thus being closer to Clarice's radicality.

\section{"A menor mulher do mundo."}

The short story "A menor mulher do mundo" was released in Laços de família, Lispector's anthology of short stories. Pontiero translates Family Ties, the complete collection into English, published by the University of Texas Press in 1972. In addition to the translation, Pontiero signs the 13-page introduction. 43 years 
later, in 2015, Clarice Lispector: Complete Stories is published by New Directions in the US and Penguin Classics in the UK, translated by Dodson with an introduction by Moser.

Dodson and Pontiero adopt different translation strategies and present different approaches concerning Lispector's rhythm. Pontiero interfered in the rhythm of Lispector's story, sometimes merging paragraphs and periods, sometimes dismembering paragraphs. Dodson maintains the extension of periods and paragraphs. It should be remembered that Pontiero's “The Smallest Woman in the World" is published 18 years before Near to the Wild Heart, which seems to indicate the consistency of his strategy: the search for the normalisation of the text.

The excerpts below are exemplary of the discrepancies between translators' strategies:

\begin{tabular}{|c|c|c|}
\hline la & (2) & \\
\hline $\begin{array}{l}\text { Foi, pois, assim que o } \\
\text { explorador descobriu, } \\
\text { toda em pé e a seus pés, } \\
\text { a coisa humana menor } \\
\text { que existe. Seu coração } \\
\text { bateu porque esmeralda } \\
\text { nenhuma é tão rara. Nem } \\
\text { os ensinamentos dos } \\
\text { sábios da Índia são tão } \\
\text { raros. Nem o homem } \\
\text { mais rico do mundo já } \\
\text { pôs olhos sobre tanta } \\
\text { estranha graça. Ali } \\
\text { estava uma mulher que } \\
\text { a gulodice do mais fino } \\
\text { sonho jamais pudera } \\
\text { imaginar. Foi então } \\
\text { que o explorador disse, } \\
\text { timidamente e com uma } \\
\text { delicadeza de sentimentos } \\
\text { de } \text { ofie cua ocna }\end{array}$ & $\begin{array}{l}\text { the } \\
\text { at his } \\
\text { man } \\
\text { His } \\
\text { urely } \\
\text { e. } \\
\text { ngs of } \\
\text { e so } \\
\text { ichest } \\
\text { as not } \\
\text { nge } \\
\text { re } \\
\text { man } \\
\text { of } \\
\text { ream } \\
\text { It was } \\
\text { r } \\
\text { with } \\
\text { of } \\
\text { would } \\
\text { him }\end{array}$ & $\begin{array}{l}\text { ered, } \\
\text { his feet, } \\
\text { n thing } \\
\text { leart } \\
\text { nerald } \\
\text { are the } \\
\text { geses of } \\
\text { ther has } \\
\text { the } \\
\text { es on } \\
\text { race. } \\
\text { woman } \\
\text { most } \\
\text { uld } \\
\text { ed. That } \\
\text { orer } \\
\text { d with a } \\
\text { of } \\
\text { uld } \\
\text { him }\end{array}$ \\
\hline
\end{tabular}




\begin{tabular}{|l|l|l|}
\hline - Você é Pequena Flor. & "You are Little Flower." & "You are Little Flower." \\
Nesse instante Pequena & At that moment, Little & At that moment Little \\
Flor coçou-se onde uma & Flower scratched herself & Flower scratched herself \\
pessoa não se coça. O & where one never scratches & where a person doesn't \\
explorador - como se & oneself. The explorer - as & scratch. The explorer - as \\
estivesse recebendo o mais & if he were receiving the & if receiving the highest \\
alto prêmio de castidade & highest prize of chastity & prize for chastity to which \\
a que um homem, sempre & to which man, always so & a man, who had always \\
tão idealista, ousa aspirar & full of ideals, dare aspire & been so idealistic, dared \\
- o explorador, tão & - the explorer who has so & aspire - the explorer, \\
vivido, desviou os olhos. & much experience of life, & seasoned as he was, \\
(194-195) & turned away his eye. (90) & averted his eyes. (166-167) \\
\hline
\end{tabular}

Table1.

The combined "toda em pé" and "a seus pés" present a double challenge: the echo of $p e ́$ in both expressions that together reinforce the idea of Little Flower's size. In this case, the combination of form and content hinders the work of the translator, since the target language does not have two expressions that combined have the scope proposed by the source text. Pontiero opts for the omission of " toda em pé" and translates only "a seus pés" for "at his feet". Dodson keeps closer to the source text and translates both expressions by "standing there at his feet". A translation springs from and produces linguistic material, there are pitfalls everywhere, and sometimes translators are left with only the resignation of the best option in the face of the impossibility of re-creation.

The above fragment prepares the objectification of Little Flower: "a coisa humana menor que existe" which only Dodson portrays with "the smallest human thing in existence". Pontiero opts for "the smallest human creature that exists", omitting, in part, the crudeness of the scene.

Next, Pontiero merges the third and fourth sentences: "Not even the teachings of the Indian sages are so rare, and even the richest man in the world has not witnessed such strange charm." By interfering in the punctuation of the text, the translator changes the rhythm of the narrative reducing the impact especially of 
the fourth sentence and preventing the parallelism proposed by the text. Dodson maintains the extension of the sentences and parallelism with her "Neither are the teachings of the sages of India as rare. Neither has the richest man in the world ever laid eyes on so much strange grace."

The construction "Ali estava uma mulher que a gulodice do mais fino sonho jamais pudera imaginar" calls attention to the unusual use of gulodice, which may pose an impasse to the translation. Dodson remains very close to the source text with "Right there was a woman the gluttony of the most exquisite dream could never have imagined". Pontiero tries to make Clarice more palatable with his "There, before his eyes, stood a woman like the delights of the most exquisite dream had never equaled." The idea of greedy gluttony is left out and a "before his eyes" is added without apparent reason. Lispector's use of gulodice, as strange as it may seem, cannot be gratuitous: it contributes to the objectification of Pequena Flor and, on the other hand, adds to the linguistic effect of the narrative.

Pontiero, besides his inclusions, tends to expand the text. In the last sentence of the above fragment, where there is "o explorador, tão vivido, desviou os olhos," Pontiero translates to "the explorer who has so much experience of life, turned away his eyes." There is no mistake, of course, but reading Dodson's translation, "the explorer, seasoned as he was, averted his eyes," the prolixity of the earlier option becomes clear.

One last fragment for analysis with culturally marked aspects that may have gone unnoticed by translators.

\begin{tabular}{|c|c|c|}
\hline Clarice (2016) & Pontiero (1972) & Dodson (2015) \\
\hline $\begin{array}{l}\text { Não tendo boneca } \\
\text { com que brincar, } \\
\text { e a maternidade já } \\
\text { pulsando terrível no } \\
\text { coração das órfãs, as } \\
\text { meninas sabidas haviam } \\
\text { escondido da freira } \\
\text { a morte de uma das } \\
\text { garotas. }\end{array}$ & $\begin{array}{l}\text { Not having any dolls to } \\
\text { play with, and maternal } \\
\text { feelings already stirring } \\
\text { furiously in their hearts, } \\
\text { some deceitful girls } \\
\text { in the orphanage had } \\
\text { concealed from the nun } \\
\text { in charge the death of } \\
\text { one of their companions. }\end{array}$ & $\begin{array}{l}\text { Having no dolls to play } \\
\text { with, and maternity } \\
\text { already pulsating } \\
\text { terribly in the hearts } \\
\text { of those orphans, the } \\
\text { sly little girls had } \\
\text { concealed another girl's } \\
\text { death from the nun. }\end{array}$ \\
\hline
\end{tabular}




\begin{tabular}{|l|l|l|}
\hline $\begin{array}{l}\text { Guardaram o cadáver } \\
\text { num armário até a } \\
\text { freira sair, e brincaram } \\
\text { com a menina morta, } \\
\text { deram-lhe banhos e } \\
\text { comidinhas, puseram-na } \\
\text { de castigo somente para } \\
\text { depois poder beijá-la, } \\
\text { consolando-a" (196) }\end{array}$ & $\begin{array}{l}\text { They kept her body in } \\
\text { played with the dead girl, } \\
\text { bathing her and feeding } \\
\text { her tidbits, and they } \\
\text { punished her only to be } \\
\text { able to kiss and comfort } \\
\text { her afterward. (91) }\end{array}$ & $\begin{array}{l}\text { They hid the corpse in } \\
\text { a wardrobe until the } \\
\text { nun left, and played } \\
\text { with the dead girl, } \\
\text { little snacks, punishing } \\
\text { her just so they could } \\
\text { consoling her. (168) }\end{array}$ \\
\hline
\end{tabular}

Table 2

Sabido and its variations in the Brazilian northeast mean smart, fast. In the above case, the smart girls hid the toy corpse from the nun. Although to our ears the story is macabre (and, in fact, it is), the lexical choice of the source text does not convey a negative tone that both "deceitful" and "sly" in the English translations do.

In "(...) deram-lhe banhos e comidinhas, puseram-na de castigo somente para depois poder beijá-la, consolando-a”, comidinha refers to playing with food, make-believe food, not that the food is real or that it is in its diminutive form, which renders "tidbits" and "little snacks" not so appropriate for the context.

Concerning Clarice's radicality, that is, her unique use of language, in this case, specifically, rhythm, lexical choice, parallelism, and repetition, Dodson's retranslation conveys a Clarice almost as singular and linguistically rich as our own.

\section{Conclusion}

One can say that Clarice has gained new impetus in the English-speaking literary system and, more than that, that the English-language reader has gained a new Clarice, a more daring, aesthetically more radical version of the author. This does not mean, however, that this development is not to a large extent due to the translations of Pontiero. A passionate promoter of literatures 
in Portuguese, Pontiero pioneered Clarice's text in English, paving the way for bolder approaches.

Entrekin's and Dodson's successful translations are part of Moser's project. According to Moser, he wanted to present a different Clarice whose texts would sound as strange and unexpected as they do in Brazil. The conscious decision of approaching Clarice's use of language instead of obliterating or normalising it was the main reason behind this investigation and was worth it: the Claricean literary radicality has gained new nuances in the target literary system, and the author has deserved the translators' artistic endeavour.

\section{References}

Levy, J. The Art of Translation. Translated by Patrick Corness. Philadelphia: John Benjamins, 2011.

Lispector, C. Perto do coração selvagem. Rio de Janeiro: Rocco, 1994.

. Near to the Wild Heart. Translated by Giovanni Pontiero. New York: New Directions, 1990.

. Near to the Wild Heart. Translated by Alison Entrekin. London: Penguin $\overline{\text { Books, }} 2014$.

2016.

. "A menor mulher do mundo". Todos os contos. Rio de Janeiro: Roxo,

. "The Smallest Woman in the World". Family Ties. Translated by Giovanni Pontiero. Austin: University of Texas Press, 1972. 
. "The Smallest Woman in the World". Family Ties. Translated by Katrina Dodson. New York: New Directions, 2015.

Moser, B. "Brazil's Clarice Lispector Gets a Second Chance in English". In: https://publishingperspectives.com/2011/12/brazil-claire-lispector-secondchance-in-english/. Accessed 02 November 2017.

Recebido em: 18/04/2018 Aceito em: 30/07/2018 Publicado em setembro de 2018

Luana Ferreira de Freitas. E-mail: luanafreitas.luana@gmail.com ORCID: https://orcid.org/0000-0003-0165-421X 